\title{
ИНТЕРТЕКСТУАЛЬНЫЕ СВЯЗИ ПАРОДИИ: ПАРАДИГМАТИЧЕСКИЙ АНАЛИЗ ЛЕКСИКИ
}

\author{
О.О. ВОРОБЙОВА. ІНТЕРТЕКСТУАЛЬНІ ЗВ'ЯЗКИ ПАРОДІЇ: ПАРАДИГМАТИЧНИЙ \\ АНАЛІЗ ЛЕКСИКИ. \\ У статті аналізуються інтертекстуальні зв'язки претекста і пародії на матеріалі
} поезї Д. Самойлова «Вільний вірш» і пародії А. Іванова «Професор, поет і Анна». Мета аналізу полягає у виявленні механізму трансформаиї парадигматичної структури лексики тексту в пародії шляхом зіставлення лексичних парадигм, щчо функиіонують в кожному тексті, $i$ виявленні відмінностей в їх складі і функиіях. Аналізується склад парадигм, характер їхнього формування, конфігураиія. Проводиться зіставлення парадигматичних схем в обох текстах, на основі якого робляться висновки про відмінності складу і функиій парадигм в претексті $і$ пародії, а також про характер трансформацій, які зазнають парадигми претекста в пародії. $У$ статті встановлено характер інтертекстуального зв'язку між пародією і претекстом, а також виявленні схеми трансформації тексту при створенні пародії. Аналіз зв'язків між прецедентним текстом і пародією дозволяє виявити механізми, за допомогою яких на парадигматичному рівні відбувається трансформачія тексту. В результаті аналізу було виявлено спрощення конфігурачії парадигм в пародї, за рахунок чого зменшується глибина тексту. Були зроблені наступні висновки: в пародії спрощується схема формування парадигм; зменшується кількість рівнів ієрархї парадигм; знижується роль інтертекстуальних зв'язків в розумінні тексту; в пародії, крім внутритекстових, формуються також міжтекстові парадигми, що зв'язують пародію з претекстом і породжсють додаткові смисли. Автор висуває гіпотезу, згідно з якою описана в статті специфіка інтертекстуального зв'язку між пародією і претекстом характерна в иілому для жанру пародії.

Ключові слова: претекст, пародія, парадигма, парадигматичний аналіз, інтертекстуальність.

\section{О.А. ВОРОБЬЕВА. ИНТЕРТЕКСТУАЛЬНЫЕ СВЯЗИ ПАРОДИИ: ПАРАДИГМАТИЧЕ-} СКИЙ АНАЛИЗ ЛЕКСИКИ.

В статье анализируются интертекстуальные связи претекста и пародии на материале стихотворения Д. Самойлова «Свободный стих» и пародии А. Иванова «Профессор, поэт и Анна». Цель анализа заключается в выявлении механизма трансформации парадигматической структуры лексики текста в пародии путем сопоставления лексических парадигм, функиионирующих в каждом тексте, и выявлении различий в их составе и функииях. Анализируются состав парадигм, характер их формирования, конфигураиия. Проводится сопоставление парадигматических схем в обоих текстах, на основе которого делаются выводы о различиях состава и функиий парадигм в претексте и пародии, а также о характере трансформаций, которые претерпевают парадигмы претекста в пародии. В статье установлен характер интертекстуальной связи между пародией и претекстом, а также выявлены схемы трансформации текста при создании пародии. Анализ связей между прецедентным текстом и пародией позволяет выявить механизмы, посредством которых на парадигматическом уровне происходит трансформаџия текста. В результате анализа было обнаружено упрощение конфигурации парадигм в пародии, за счет чего уменьшается глубина текста. Были сделаны следующие выводыр: в пародии упрощается схема формирования парадигм; уменьшается количество уровней иерархии парадигм; снижается роль интертекстуальных связей в понимании текста; в пародии, помимо внутритекстовых, формируются также межтекстовые парадигмы, связывающие пародию с претекстом и порождающие дополнительные смыслы. Автор выдвигает гипотезу, согласно которой описанная в статье специфика интертекстуальной связи между пародией и претекстом характерна в целом для жанра пародии.

Ключевые слова: претекст, пародия, парадигма, парадигматический анализ, интертекстуальность.

(C) О.А. Воробьева, 2019

https://doi.org/10.34142/2312-1572.2019.01.67.04 


\section{O.A. VOROBYEVA. INTERTEXTUAL TIES OF PARODIA: PARADIGMATIC ANALYSIS OF} VOCABULARY.

The article analyzes the intertextual connections of the pretext and parody on the material of D. Samoilov's poem "Free verse" and A. Ivanov's parody "Professor, poet and Anna". The purpose of the analysis is to identify the transformation mechanism of the paradigmatic structure of the text vocabulary in parody by comparing the lexical paradigms that function in each text, and identify differences in their composition and functions. The composition of paradigms, the nature of their formation, configuration are analyzed. A comparison is made of paradigmatic schemes in both texts, on the basis of which conclusions are drawn about the differences in the composition and functions of paradigms in the pretext and parody, as well as on the nature of the transformations that undergo parademics in the pretext in parody. The article establishes the nature of the intertextual connection between the parody and the pretext, as well as the identification of the text transformation schemes during the creation of the parody. An analysis of the links between the precedent text and the parody reveals the mechanisms by which the text is transformed at the paradigmatic level. As a result of the analysis, a simplification of the paradigm configuration in the parody was discovered, thereby reducing the text depth. The following conclusions were made: in paradia, the paradigm formation scheme is simplified; decreases the number of levels of paradigm hierarchy; the role of intertextual links in the understanding of the text is reduced; in parodies, in addition to in-text, intertextual paradigms are also formed, linking parody with pretext and generating additional meanings. The author puts forward the hypothesis according to which the specificity of the intertextual connection between parody and pretext described in the article is characteristic in general of the genre of parody.

Keywords: pretext, parody, paradigm, paradigmatic analysis, intertextuality.

Интертекстуальные отношения в последние десятилетия все чаще становятся предметом научного внимания филологов. Одним из проявлений интертекстуальности является пародирование. В общей классификации межтекстовых взаимодействий, разработанной французским литературоведом Жераром Женеттом в книге «Палимпсесты: литература во второй степени» (1982; рус. перевод 1989), осмеяние или пародирование одним текстом называется гипертекстуальностью. Понимаемое таким образом явление гипертекстуальности может быть исследовано в различных аспектах. Одним из таких аспектов является аспект сопоставления парадигматической структуры лексики претекста (исходного текста) и вторичного текста.

Парадигматическая структура лексики текста рассматривается как ряды связанных между собой различными оппозициями «предметных» образов (парадигм), объединенных в единую систему (гиперпарадигму). Формирование гиперпарадигмы в сознании воспринимающего текст - аналог процесса понимания текста [4].

Цель данной статьи заключается в сопоставлении парадигматической структуры лексики стихотворения Д. Самойлова «Свободный стих» и пародии А. Иванова «Профессор, поэт и Анна». Подобное сопоставление позволяет поставить вопрос о типичных для пародии интертекстуальных (гипертекстуальных) связях.

Доминантная лексическая парадигма в стихотворении Д. Самойлова - перечисление событий, выдержать которые достаточно сложно гибкому мозгу. Эта парадигма распадается на несколько частных парадигм, соотносящихся с различными аспектами действительности, враждебной человеку, лишающей его свободы. Их восприятие не под силу гибкому мозгу, т.е. мозгу, способному реагировать на изменения внешней среды, изменение обстоятельств жизни человека: скорость, интенсивность изменений окружающего мира: городской гул, скорости, крик динамиков, новости, телевидение; неурядицы личной жизни: семейные дрязги, похороны, отсутствие денег, неразделенная любовь, актерские маски; страх ожидания войны: артиллерия, прения сторон, угрозы; все новое и не до конца понятное, что появляется в мире: прогресс в медицине, ложные учения, прогресс наук и успех поэзии; законодательство, понятие о бесконечности и собственное несовершенство также входят в ряд наименований враждебного человеку мира. Эти парадигмы противопоставлены названию стихотворения «Свободный стих». Отсутствие логической последовательности, упорядоченности компонентов парадигм не случайно. Многоаспектность, многочисленность, мозаичность и хаотичность враждебных мозгу человека жизненных обстоятельств придают миру лирического героя стихотворения Д. Самойлова черты сюрреалистичности, которые сближают его с миром героев Кафки - миром отчуждения, экзистенциального беспокойства, вины и абсурда [3]. 
Оценка этого мира - в противопоставлении Уильяма Эшби Францу Кафке, произведения которого, «как правило, повествуют о человеке, сталкивающемся с причудливыми или сюрреалистическими трудностями и непонятными социальными бюрократическими силами» [там же]:

Мне хочется верить профессору Эшби

И не хочется верить писателю Кафке.

Лирический герой по-своему интерпретирует гибкость/негибкость мозга - как возможность отказаться от восприятия мозаичной сюрреалистической враждебности мира, уйти от нее (негибкость) и быть погруженным в нее и раздавленным ею, подобно герою Кафки (гибкость).

Последние 4 строки - прямое обращение к читателю с призывом выключить радио и, придя в себя, отрешиться от всего, что прогибает мозг, рационально осмыслить окружающий мир, не дать ему раздавить себя.

Таким образом, основные парадигмы стихотворения: оценочная (последние 6 строк прямая оценка), мозг и его характеристики как гибкого в прямом и переносном смысле явления, факторы, враждебные мозгу.

Образ гибкая система мозга в стихотворении Д. Самойлова «опредмечен» благодаря связи с парадигмой признаков предметного мира (cmoum, как телеграфный столб; гудит; прогнулся, как лист жести, остается прямым). Собственно психологическое содержание он приобретает лишь в первой строке, где он связан с именем У.Р. Эшби - знаменитого ученого, специалиста в области психологии и кибернетики. Включенность в две парадигмы формирует метафоричность слова гибкость, что, собственно, и дает основания для пародирования стихотворения А. Ивановым.

Рассматривая конфигурацию парадигм претекста, можно увидеть, что доминирующей в нем является оценочная парадигма, которой подчинены парадигма характеристик мозга (в свою очередь, сформированная «предметной» и «психологической» парадигмами) и парадигма враждебных ему явлений. Подобная схема предусматривает трехступенчатую иерархию парадигм, активно участвующую в формировании глубины текста. Подчиненные парадигмы становятся своего рода логической основой, которая формирует итоговую оценку. В свою очередь, две парадигмы в составе парадигмы характеристик мозга делают ее более объемной и выразительной, создавая двуплановость восприятия понятия «гибкой системы» - в прямом и переносном смыслах.

Парадигматическая структура пародии свидетельствует о ее «заземленности» по сравнению с претекстом. Если в претексте парадигма «предметы быта» выполняет частную функцию, входя в перечисление факторов, отрицательно влияющих на человека, то в пародии соответствующая парадигма становится основной, определяющей ее тональность: соседка, ucmonница ЖЭКа, присядем, кричала, хрен с ним, опилки, того гляди. Основным приемом, который используется А. Ивановым, является прием двойного контрастного, часто алогичного противопоставления парадигм, вызывающего эффект комического. С одной стороны, «заземляющая» парадигма противопоставлена парадигме «высоких» научных искусствоведческих терминов (экзистенциализм - с упоминанием известнейшего представителя этого философского и эстетического направления Сартра - барокко, эклектизм, контрапункт). Другая линия противопоставления с парадигмой Анна, похожая на мадонну, мадонна Анна, ах, боже, прошу вас, Ан$н а$ активизирует интертекстуальные связи с парадигмой образов других произведений Д. Самойлова, в частности стихотворения «Пестель, поэт и Анна», о чем свидетельствует явная параллель в названии пародии «Профессор, поэт и Анна»:

Там Анна пела с самого утра

И что-то шила или вышивала.

И песня, долетая со двора,

Ему невольно сердие волновала.

$$
<\ldots>
$$

Он вновь усльшал-распевает Анна.

И задохнулся:

"Анна! Боже мой!"

По сравнению с прецедентным текстом, где образ Анны - высокий образ возлюбленной Пестеля, в пародии это образ истопницы ЖЭКа. 
Новое наименование профессора - автора теории гибкости мозга - фон Остен-Бакен (аллюзия к произведению И. Ильфа и Е. Петрова «Золотой теленок»: «чего хотел добиться друг моего детства Коля Остен-Бакен от подруги моего же детства, польской красавицы Инги Зайонц. Он добивался любви» [2]]). Аллюзия подкрепляет включение имени автора новоявленной теории замены мозга опилками в соответствующую оценочную парадигму.

Еще одной антитезой является связь парадигмы атрибутов алогичного самого по себе ученого разговора лирического героя, именуемого мосье, с истопницей Анной и неожиданного вывода, к которому пришли собеседники с опилками в голове, способными отсыреть: да хрен с ним, с профессором этим. Не стоит о нем и думать.

Конфигурации парадигм в данном тексте значительно проще, чем в претексте: основной также является парадигма оценки, которой подчинены парадигмы быта, образа Анны и «ученого разговора». Все перечисленные ряды относятся к парадигмам первого уровня, т.е. не являются гиперпарадигмами.

Таким образом, в тексте наблюдается двухступенчатая иерархия парадигм. Вспомогательные парадигмы образуют тот фон, на котором формируется общая оценка происходящего и создают необходимый контраст, который становится источником комизма. Следует отметить также и то, что разным парадигмам присущи различные стили - от «научного» до нейтрального и просторечного, что усиливает общий эффект абсурдности и комичности.

Сопоставление и противопоставление внутритекстовых доминантных парадигм претекста и пародии дает основания для следующих выводов.

1. Претекст и пародия характеризуются разной степенью сложности парадигматической организации. В стихотворении Д. Самойлова установление связи между парадигмами - осмысление читателем опасности превращения человека в героя Кафки - требует определенного запаса фоновых знаний. Кроме того, оппозиции, формирующие отдельные парадигмы, также определяются с большей степенью затрудненности. В пародии сложности претекста сводятся к упрощенным и очевидным. При этом упрощение парадигматической структуры не определяется уменьшением количества парадигм - их может быть больше, чем в претексте. Однако можно заметить упрощение самой конфигурации парадигм и уменьшение количества уровней их иерархии в тексте, что также влияет на его глубину.

2. Близкие синтаксические структуры (например, ряды однородных членов) в претексте и пародии характеризуются различным лексическим наполнением. У Д. Самойлова это имена обстоятельств, лишающих человека свободы, перечисление которых вполне уместно и обоснованно в контексте произведения. У А. Иванова ряд однородных членов - «интеллектуальные» термины, значение которых понятно лишь специалистам. Поскольку они употребляются в беседе с истопницей ЖЭКа, ситуация воспринимается как абсурдная. В основе связей между отдельными парадигмами в пародии лежит алогичность.

3. Абсурдность парадигматических оппозиций в пародии ощущается на фоне соответствующих оппозиций в претексте, т.е. формируются не только внутритекстовые, но и межтекстовые парадигмы. Так, профессор У.Р. Эшби превращается в друга детства Остапа Бендера Колю Остен-Бакена, добившегося любви подруги детства Инги Зайонц, негибкость структуры мозга превращается в замену мозга опилками, Анна, возлюбленная Пестеля, становится истопницей ЖЭКа и т.п. Иными словами, абсурдность человеческого бытия превращается в абсурдность быта.

4. Хотя в пародии шире, чем в претексте, представлены интертекстуальные связи, парадигмы формируются на их основе с меньшей степенью затрудненности. Причем именно интертекстуальные связи у А. Иванова становятся предметом пародирования. В стихотворении Д. Самойлова это связь с теорией Эшби и произведениями Кафки, у Иванова круг интертекстов расширяется, кроме связи с пародируемым текстом, появляются связи со стихотворением Д. Самойлова «Пестель, поэт и Анна», романом И. Ильфа и Е. Петрова «Золотой теленок». Важно также отметить, что осмысление интертекстуальных связей в претексте является обязательным для понимания стихотворения Д. Самойлова, осмысление же интертекстуальных связей в пародии в значительной степени не определяет понимание текста в целом.

5. Обращают на себя внимание функционально-стилевые отличия оригинала от пародии. Если у Д. Самойлова произведение выдержано в едином стиле, то в пародии наблюдается эффект оппозиций разностилевых парадигм. Нейтральный стиль большей части пародии противопоставляется, с одной стороны, книжному стилю искусствоведческих терминов, с другой - 
разговорному (и даже грубо разговорному) стилю в конце произведения. Эти противопоставления направлены на подкрепление идеи абсурдности связей между текстовыми парадигмами.

6. Таким образом, основными отличиями парадигматической организации пародии и претекста являются прежде всего абсурдность предлагаемых автором оппозиций, упрощение формирования парадигм и связей между ними, т.е. уменьшение глубины текста, понимаемой как степень сложности его восприятия.

\section{ЛИТЕРАТУРА}

1. Иванов А. Пародии / Электронный ресурс. Адрес доступа: http://litparody.ru/autors/ivanov-aleksandr/professor-poet-i-anna.html

2. Ильф И.А., Петров Е.П. Золотой теленок / Электронный ресурс. Адрес доступа: http://book-online.com.ua/read.php?book=5281

3. Кафка, Франц. Материалы из Википедии. URL: https://ru.wikipedia.org/wiki/\%D0\%9A\%D0\%B0\%D1\%84\%D0\%BA\%D0\%B0,_D0\%A4\%D1\%80 $\% \mathrm{D} 0 \% \mathrm{~B} 0 \% \mathrm{D} 0 \% \mathrm{BD} \% \mathrm{D} 1 \% 86$ (дата обращения: 15.01.2019)

4. Парадигматический анализ поэтической лексики: коллективная монография / И.И. Степанченко, М.П. Мирошниченко, К.В.Нестеренко, М.В. Пехарева, О.П. Просяник. Киев: «Українське видавництво», 2014. 216 с.

5. С. Есенин и его окружение: А. Мариенгоф - Н. Клюев - С. Клычков: сопоставительный анализ лексики: коллективная монография / И.И. Степанченко, Е.В. Гончар, М.П. Мирошниченко, К.В.Нестеренко, М.В. Оробинская, О.П. Просяник. Харьков: «Видавництво Іванченка I. C.», 2016.

6. Самойлов Д. Стихи. URL: https:// 45parallel.net/david_samoylov/svobodnyy_stikh_professor_uilyam_ross_eshbi.html (дата обращения: 20.12.2018) 